\title{
PENGARUH STRATEGI GENIUSLEARNINGTERHADAP HASIL BELAJAR FISIKA SISWA PADA MATERI POKOK SUHU DAN KALOR KELAS X SEMESTER II DI SMA NEGERI 1 SIABU T.A. 2013/2014.
}

\author{
Romaisah Nasution dan dan Eva Ginting \\ Jurusan Fisika FMIPA Universitas Negeri Medan \\ nasutionromaisah@ymail.com
}

\begin{abstract}
ABSTRAK
Penelitian ini bertujuan untuk mengetahui hasil belajar fisika siswa, aktivitas belajar siswa dan apakah ada pengaruh strategi Genius Learning terhadap hasil belajar fisika siswa pada materi pokok Suhu dan Kalor kelas $\mathrm{X}$ Semester II di SMA N 1 Siabu. Genius Learning merupakan suatu strategi yang menggunakan pengetahuan yang berasal dari berbagai disiplin ilmu seperti pengetahuan tentang cara kerja otak, cara kerja memori, neuro-linguistic programming, motivasi, konsep diri, kepribadian, emosi, perasaan, pikiran, metakognisi dan gaya belajar. Tujuan strategi Genius Learning adalah untuk meningkatkan hasil belajar dan berperan aktifnya siswa dalam proses pembelajaran. Jenis penelitian ini adalah quasi eksperimen dengan populasi siswa kelas X SMA N 1 Siabu, dengan sampel penelitian siswa kelas X-1 kelas eksprimen dan siswa kelas X-2 kelas kontrol. Semua tahap Genius Learning telah dilakukan dengan baik didapat aktivitas belajar siswa dalam kategori aktif. Berdasarkan hasil tes belajar didapatkan nilai rata-rata postes kelas eksperimen adalah 77,34. Dilakukan perhitungan data dengan menggunakan uji-t satu pihak dengan $\alpha=0,05$, didapat bahwa $t_{\text {hitung }}>t_{\text {tabel }}$ yang berarti $\mathrm{H}_{\mathrm{a}}$ diterima. Berdasarkan hasil analisis didapatkan bahwa nilai hasil belajar fisika kelas eksperimen lebih tinggi daripada kelas kontrol, dari hasil perhitungan dan analisis data bahwa ada perbedaan yang signifikan akibat pengaruh strategi Genius Learning terhadap hasil belajar fisika siswa pada materi pokok Suhu dan Kalor kelas X Semester II di SMA N 1 Siabu.
\end{abstract}

Kata Kunci: Genius Learning, hasil belajar, aktivitas belajar 


\section{PENDAHULUAN}

Pada dasarnya pendidikan adalah laksana eksprimen yang tidak pernah selesai sampai kapanpun, sepanjang ada kehidupan manusia di dunia ini. Dikatakan demikian, karena pendidikan merupakan bagian dari kebudayaan dan peradaban manusia yang terus berkembang. Hal ini sejalan dengan pembawaan manusia yang memiliki potensi kreatif dan inovatif dalam segala bidang kehidupannya( Hasbullah, 2008:i).

Menurut Rohani, A. (2004:4), Pendidikan secara umum adalah suatu proses kehidupan dalam mengembangkan diri tiap individu untuk dapat hidup dan melangsungkan kehidupan, sehingga menjadi manusia yang terdidik yang nantinya akan tumbuh menjadi seorang manusia dewasa yang akan berinteraksi dan melakukan banyak hal terhadap lingkungannya, baik secara individu maupun sebagai makhluk sosial.

Tujuan belajar fisika adalah untuk memberikan pengetahuan dan pemahaman terhadap penerapan konsep-konsep fisika dan metode ilmiah yang melibatkan ketrampilan proses untuk memecahkan berbagai permasalahan dalam kehidupan sehari-hari. (Anasofiana, 2010:09:30)

Disamping itu, melalui ilmu fisika akan tersingkap rahasia alam, penemuan baru dan teknologi terapan yang sangat bermanfaat bagi kehidupan manusia. Sesuai tuntutan ini maka, proses pembelajaran fisika haruslah aktif dan menyenangkan. Dengan menerapkan pembelajaran yang didasarkan pada karakteristik yaitu kecerdasan siswa akan membuat semua siswa menikmati pembelajaran fisika. Untuk itu diperlukan suatu model pembelajaran yang bisa mengemas masing-masing karakter siswa tentunya dengan caracara yang lebih menyenangkan. (syahalam, 2013:04)

Genius Learning merupakan proses pembelajaran yang bersifat efesien, efektif dan menyenangkan. Pendekatan yang digunakan dalam Genius Learning membantu anak didik untuk mengerti kekuatan dan kelebihan mereka yang sesuai dengan gaya belajar mereka masing-masing (Gunawan,2012:6). Dengan menggunakan strategi Genius Learning nantinya siswa akan belajar cara belajar yang benar sesuai keunikan mereka masing-masing. Strategi ini diharapkan dapat membantu guru untuk menciptakan kegiatan pembela jaran yang menyenangkan dan siswa menjadi lebih termotivasi untuk belajar. Jika motivasi belajar siswa meningkat maka diharapkan nilai hasil belajarnya juga berpengaruh meningkat.

Berdasarkan uraian di atas, maka penulis melakukan penelitian dengan judul "Pengaruh Strategi Genius Learning Terhadap Hasil Belajar Fisika Siswa Pada Materi Pokok Suhu Dan Kalor kelas X semester II di SMA Negeri 1 Siabu T.A. 2013/2014". Rumusan masalah pada penelitian ini adalah:(1) Bagaimana hasil belajar fisika siswa yang diberi perlakuan strategi Genius Learning pada materi pokok Suhu dan Kalor kelas X Semester II di SMA $\mathrm{N} 1$ Siabu ? (2) Bagaimana aktivitas 
belajar siswa yang diberi perlakuan strategi Genius Learning dengan pembelajaran konvensional pada materi pokok Suhu dan Kalor kelas X Semester II di SMA N 1 Siabu? (3) Apakah ada pengaruh strategi Genius Learning terhadap hasil belajar fisika siswa pada materi pokok Suhu dan Kalor kelas X Semester II di SMA N 1 Siabu?

Tujuan penelitian ini adalah: (1) Untuk mengetahui hasil belajar siswa yang diberi perlakuan strategi Genius Learning dengan menggunakan pembelajaran konvensional pada materi pokok Suhu dan Kalor kelas X Semester II di SMA N 1 Siabu? (2) Untuk mengetahui aktivitas belajar siswa yang diberi perlakuan strategi Genius Learning dengan pembelajaran konvensional pada materi pokok Suhu dan Kalor kelas X Semester II di SMA N 1 Siabu? (3) Untuk mengetahui apakah ada pengaruh strategi Genius Learning terhadap hasil belajar fisika siswa pada materi pokok Suhu dan Kalor kelas X Semester II di SMA N 1 Siabu?

Batasan masalah dalam penelitian ini adalah: (1) Penelitian ini dilakukan di SMA N 1 Siabu dan subjek yang di teliti adalah siswa kelas X semester II Tahun Ajaran 2013/2014. (2) Strategi pembelajaran yang digunakan strategi Genius Learning dan pembelajaran konvensional.

Materi yang digunakan dalam penelitian ini adalah Suhu dan Kalor.

Startegi Genius Learning juga disebut Holistic Learning adalah istilah yang digunakan untuk menjelaskan suatu pendekatan peraktis dalam upaya meningkatkan hasil proses pembelajaran. Upaya peningkatan ini dicapai dengan menggunakan penetahuan yang berasal dari disiplin ilmu seperti pengetahuan tentang cara kerja otak, cara kerja memori, neuro-linguistic programming, motivasi, konsep diri, kepribadian, emosi, perasaan, pikiran, metakognisi, gaya belajar, multiple intelligences atau kecerdasan majemuk, , dan teknik belajar lainnya. (Gunawan, 2012:2).



Gambar 1. Tahapan Genius Learning Strategy (Gunawan, 2012:334)

Karakteristik pembelajaran Staregi Genius Learning:

1. Pembelajaran berpusat pada siswa (student center)

2. Pengetahuan yang diperoleh dari pengalaman siswa sendiri akan disimpan dalam jangka panjang

3. Siswa tidak sekedar menghafal pelajaran tetapi dapat belajar sambil bermain dengan menerapkan kedelapan tahap tersebut

\section{METODE}

Jenis penelitian ini termasuk penelitian quasi eksperimen, yaitu merupakan penelitian yang bertujuan untuk mengetahui ada tidaknya perbedaan akibat pengaruh. Penelitian ini dilaksanakan di SMA N 1 Siabu yang beralamat di Jalan Medan Padang, Kecamatan Siabu, 
Kabupaten Mandailing Natal dan pelaksanaannya pada semester II T.A. 2013/2014. Populasi adalah siswa kelas X yang terdiri dari kelas 7 kelas yaitu dari kelas X-1 sampai X-7 yang berjumlah 240 siswa. Sampel dalam penelitian ini terdiri dari dua kelas yaitu kelas kontrol dan kelas eksperimen. Teknik pengambilan sampelnya yaitu dengan sampel random atau sampel acak atau sampel campur, Variabel penelitian ini terdiri atas dua jenis yaitu variabel bebas dan veriabel terikat.Variabel bebas dalam penelitian ini adalah penerapan Strategi Genius Learning dan pembelajaran konvensional. Variabel terikat dalam penelitian ini adalah hasil belajar siswa pada materi suhu dan kalor, Penelitian ini melibatkan dua kelas yang diberi perlakuan yang berbeda. Untuk mengetahui perbedaan hasil belajar fisika dengan perlakuan yang berbeda tersebut, siswa akan diberikan tes. Tes yang dilakukan yaitu pretes (sebelum diberi perlakuan) dan postes (setelah diberikan perlakuan). Desain penelitiannya two group pretestpostest design. Desain penelitian ini dapat dilihat pada tabel berikut ini:

Tabel 1. Two Group Pretes - Posttes

\section{Design}

\begin{tabular}{|l|c|c|c|}
\hline Kelompok & Pretes & Perlakuan & Postes \\
\hline $\begin{array}{l}\text { Kelas } \\
\text { eksperimen }\end{array}$ & $\mathrm{T}_{1}$ & $\mathrm{X}$ & $\mathrm{T}_{2}$ \\
\hline $\begin{array}{l}\text { Kelas } \\
\text { control }\end{array}$ & $\mathrm{T}_{1}$ & $\mathrm{Y}$ & $\mathrm{T}_{2}$ \\
\hline
\end{tabular}

(Arikunto, S., (2010),

$\mathrm{T}_{1}=$ Pretes diberikan kepada kelas eksperimen dan kelas kontrol sebelum perlakuan
$\mathrm{T}_{2}=$ Postes diberikan setelah perlakuan pada kelas eksperimen dan kelas kontrol

$\mathrm{X}=$ Pembelajaran dengan menerapkan Stategi Genius Learning pada materi pokok suhu dan kalor

$\mathrm{Y}=$ Pembelajaran dengan menerapkan pembelajaran konvensional pada materi pokok suhu dan kalor

Instrumen dalam penelitian ini adalah

1. Tes hasil belajar

2. Angket Lembar aktivitas siswa

\section{HASIL DAN PEMBAHASAN}

\section{Hasil Penelitian}

Sebelum perlakuan dimulai, terlebih dahulu diberi pretes yang bertujuan untuk mengetahui kemampuan awal siswa. Setelah dilakukannya pretes dan perhitungan hasil pretes didapatkan sbb:

Tabel 2. Data nilai pretes kelas eksperimen dan kelas kontrol

\begin{tabular}{|c|c|c|c|c|c|}
\hline \multicolumn{3}{|c|}{$\begin{array}{l}\text { Pretes Kelas } \\
\text { Eksperimen }\end{array}$} & \multicolumn{3}{|c|}{$\begin{array}{c}\text { Pretes Kelas } \\
\text { Kontrol }\end{array}$} \\
\hline Nilai & $f$ & $\begin{array}{l}\text { Rata- }^{-} \\
\text {rata }\end{array}$ & Nila & $f$ & $\begin{array}{l}\text { Rata- } \\
\text { rata }\end{array}$ \\
\hline 10 & 2 & \multirow{9}{*}{30,94} & 10 & 0 & \multirow{9}{*}{34,38} \\
\hline 15 & 1 & & 15 & 0 & \\
\hline 20 & 4 & & 20 & 4 & \\
\hline 25 & 4 & & 25 & 4 & \\
\hline 30 & 4 & & 30 & 6 & \\
\hline 35 & 9 & & 35 & 6 & \\
\hline 40 & 4 & & 40 & 5 & \\
\hline 45 & 4 & & 45 & 4 & \\
\hline 50 & 0 & & 50 & 3 & \\
\hline
\end{tabular}

Setelah itu dilakukan uji persyaratan analisa data meliputi uji normalitas serta uji homogenitas data pretes. Pengujian normalitas data 
dilakukan dengan menggunakan uji Liliefors. Dari uji ini diperoleh bahwa nilai pretes kedua kelompok sampel memiliki data yang normal atau $\mathrm{L}_{\text {hitung }}<\mathrm{L}_{\text {tabel }}$ pada taraf signifikansi 0,05 dan $\mathrm{N}=32$, Hasil uji normalitas data pretes kedua kelas adalah

Tabel 3. Uji Normalitas Data Pretes Kelas Eksperimen dan Kontrol.

\begin{tabular}{|c|c|c|c|}
\hline \multirow{2}{*}{ Kelompok } & \multirow{2}{*}{$\mathrm{N}$} & \multicolumn{2}{|c|}{ Data pretes } \\
\cline { 3 - 4 } & & Lhitung & Ltabel \\
\hline Eksperimen & 32 & 0.09 & \multirow{2}{*}{0,16} \\
\hline Kontrol & 32 & 0.12 & \\
\hline \multicolumn{2}{|c|}{ Uji homogenitas dilakukan }
\end{tabular}
dengan menggunakan uji $\mathrm{F}$ untuk mengetahui apakah kelompok sampel berasal dari populasi yang homogen atau tidak. Dan hasil yang didapatkan adalah

Tabel 4. Uji Homogenitas Data Pretes Kelas Eksperimen dan Kontrol

\begin{tabular}{|l|c|c|c|}
\hline \multicolumn{1}{|c|}{ Data } & $\mathrm{S}$ & $\mathrm{F}_{\text {hitung }}$ & $\mathrm{F}_{\text {tabel }}$ \\
\hline Eksperimen & 97,42 & \multirow{2}{*}{1,15} & 1,82 \\
\hline Kontrol & 85,00 & & \\
\hline
\end{tabular}

hal ini terlihat dari harga $\mathrm{F}_{\text {tabel }}=$ 1,82 . Karena $F_{\text {hitung }}<F_{\text {tabel, }}$ maka data pretes kedua sampel berasal dari populasi yang homogen.

Sehingga dapat disimpulkan bahwa data penelitian telah memenuhi persyaratan untuk dilakukan penelitian.

Kemudian kedua kelas diberi perlakuan yang berbeda. Kelas eksperimen diberi perlakuan dengan pembelajaran dengan menggunakan StrategiGenius Learningdan kelas kontrol diberi perlakuan dengan menggunakan pembelajaran konvensional. Kedua kelas diberi perlakuan selama tiga kali pertemuan, selama proses pembelajaran berlangsung aktivitas siswa dinilai, dan didapatkan ratarata ketiga pertemuan aktif, artinya selama proses pembelajaran siswa terlibat aktif didalamnya, yang tertulis tabel dibawah ini:

Tabel 5. Rata - Rata Aktivitas Belajar Siswa Per Indikator

\begin{tabular}{|c|c|c|c|c|}
\hline \multirow{2}{*}{ Indikator } & \multicolumn{3}{|c|}{ Kelas } & \multirow{2}{*}{$\begin{array}{c}\text { Rata- } \\
\text { Eksprimen }\end{array}$} \\
\cline { 2 - 4 } & I & II & III & rata \\
\hline $\begin{array}{c}\text { Melakukan } \\
\text { Senam otak }\end{array}$ & 59 & 70 & 85 & 71,47 \\
\hline Apersepsi & 59 & 95 & 84 & 79,33 \\
\hline Perhatian & 68 & 78 & 88 & 78 \\
\hline $\begin{array}{c}\text { Menyampaika } \\
\text { n tujaun }\end{array}$ & 79 & 79 & 90 & 82,9 \\
\hline $\begin{array}{c}\text { Memberikan } \\
\text { pertanyaan }\end{array}$ & 49 & 74 & 90 & 71,07 \\
\hline $\begin{array}{c}\text { Memberikan } \\
\text { jawaban }\end{array}$ & 44 & 68 & 79 & 63,67 \\
\hline Aktivasi & 79 & 78 & 84 & 80,33 \\
\hline $\begin{array}{c}\text { Permainan } \\
\text { penutup }\end{array}$ & 74 & 84 & 90 & 82,73 \\
\hline $\begin{array}{c}\text { Rata - Rata } \\
\text { Total }\end{array}$ & \multicolumn{3}{|c|}{76,19} & Aktif \\
\hline
\end{tabular}

Dari tabel tersebut dapat disimpulkan selama tiga pertemuan berlanjut proses pembelajaran didalamnya siswa terlibat aktif

Selama pembelajaran berlangsung terdapat 3 siswa yang sangat aktif atau 9\%, 16 siswa yang tergolong aktif atau 50\%, 13 siswa yang tergolong cukup aktif atau $41 \%$, sedangkan siswa yang kurang aktif dan siswa sangat tidak aktif tidak ada atau $0 \%$.

Secara ringkas rata-rata aktivitas siswa selama tiga pertemuan adalah sbb: 


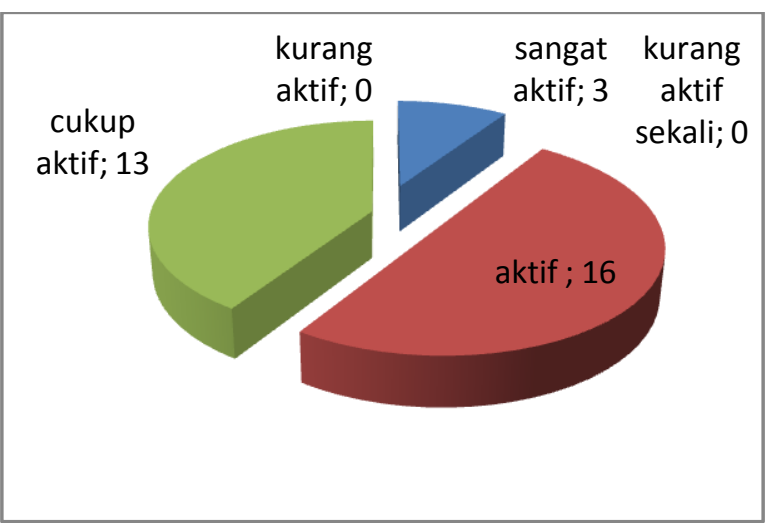

Gambar 3. rata-rata aktivitas siswa selama tiga kali pertemuan.

Hal ini menunjukkan bahwa siswa memiliki ketertarikan terhadap penerapan StrategiGenius Learning pada materi pokok suhu dan kalor semester II di SMA N 1 siabu

Hasil yang sama juga ditemukan oleh Devi (2014), dimana siswa lebih termotivasi untuk belajar dan lebih berani menyampaikan pendapat setelah diterapkannya Strategi Genius Learning, yang artinya siswa memiliki ketertarikan terhadap penerapan StrategiGenius Learning

Setelah diberikan perlakuan pada masing-masing kelas maka untuk mengetahui hasil belajar siswa diadakan postes. Dari hasil diperoleh bahwa nilai rata-rata postes kelas Eksperimen adalah 77,34 dan kelas kontrol adalah 65,94. Perbandingan nilai postes antara kedua kelas dapat dilihat pada tabel 6 . berikut:

Tabel 6. Data nilai postes kelas eksperimen dan kelas kontrol

\begin{tabular}{|c|c|c|c|c|c|}
\hline \multicolumn{3}{|c|}{$\begin{array}{l}\text { Postes Kelas } \\
\text { Eksperimen }\end{array}$} & \multicolumn{3}{|c|}{$\begin{array}{c}\text { Postes Kelas } \\
\text { Kontrol }\end{array}$} \\
\hline Nilai & f & Rata & Nilai & $f$ & Rata- \\
\hline 50 & 1 & \multirow{4}{*}{77,34} & 50 & 2 & \multirow{4}{*}{65,94} \\
\hline 5ら & 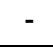 & & & 2 & \\
\hline 60 & 2 & & 60 & 8 & \\
\hline 65 & & & 65 & 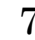 & \\
\hline
\end{tabular}

\begin{tabular}{|c|c|c|c|}
\hline 70 & 5 & 70 & 8 \\
\hline 75 & 4 & 75 & 2 \\
\hline 80 & 12 & 80 & 1 \\
\hline 85 & 6 & 85 & 2 \\
\hline 90 & 2 & 90 & - \\
\hline
\end{tabular}

Hasil ini juga didukung oleh hasil penelitian yang dilakukan oleh Suliyono (2012), dimana nilai prestasi belajar fisika siswa yang belajar dengan Strategi Genius Learning lebih tinggi dibandingkan hasil belajar siswa yang diberikan dengan pembelajaran konvensional

Uji persyaratan analisa data meliputi uji normalitas serta uji homogenitas data pretes. Pengujian normalitas data dilakukan dengan menggunakan uji Liliefors. Dari uji ini diperoleh bahwa nilai pretes kedua kelompok sampel memiliki data yang normal atau $\mathrm{L}_{\text {hitung }}<\mathrm{L}_{\text {tabel }}$ pada taraf signifikansi 0,05 dan $\mathrm{N}=32$, adalah

Tabel 7. Uji Normalitas Data Postes

Kelas Eksperimen dan Kontrol.

\begin{tabular}{|c|c|c|c|}
\hline \multirow{2}{*}{ Kelompok } & \multicolumn{2}{|c|}{ Data postes } & \multirow{2}{*}{$\mathrm{N}$} \\
\cline { 2 - 3 } & L hitung & Ltabel & \\
\hline Eksperimen & 0.13 & \multirow{2}{*}{0,16} & 32 \\
\hline Kontrol & 0.14 & & 32 \\
\hline
\end{tabular}

Hasil uji homogenitas postes diperoleh nilai $\mathrm{F}_{\text {hitung }}=1,01$. Pada taraf signifikansi $\alpha=0,05$ diperoleh harga $F_{\text {tabel }}=1,82$. Karena $F_{\text {hitung }}<$ $\mathrm{F}_{\text {tabel, }}$ maka data postes kedua sampel homogen, adalah sbb:

Tabel 8. Uji Homogenitas Data Postes Kelas Eksperimen dan Kelas Kontrol

\begin{tabular}{|l|c|c|c|}
\hline Data & $\mathrm{S}$ & $\mathrm{F}_{\text {hitung }}$ & $\mathrm{F}_{\text {tabel }}$ \\
\hline $\begin{array}{l}\text { Postes } \\
\text { Eksperimen }\end{array}$ & 75,86 & \multirow{1}{*}{1,01} & 1,82 \\
\cline { 1 - 2 } $\begin{array}{l}\text { Postes } \\
\text { Kontrol }\end{array}$ & 74,82 & & \\
\hline
\end{tabular}

Sehingga dapat disimpulkan bahwa data penelitian telah memenuhi persyaratan untuk 
dilakukan pengujian hipotesis penelitian.

Pengujian hipotesis data hasil penelitian dilakukan dengan menggunakan uji $t$ dua pihak dan uji $t$ satu pihak. Uji t dua pihak digunakan untuk mengetahui kesamaan kemampuan awal siswa pada kedua kelompok sampel sedangkan uji $\mathrm{t}$ satu pihak digunakan untuk mengetahui apakah hasil belajar siswa dengan menerapkan Strategi Genius Learning.

Hasil pengujian hipotesis dua pihak diperoleh harga thitung $<t_{\text {tabel }}$ yaitu $1,500<2,002$ maka diperoleh kesimpulan bahwa antara kelas eksperimen dan kelas kontrol mempunyai kemampuan awal yang sama. Secara ringkas, hasil perhitungan uji hipotesis data pretes tertera dalam tabel 9. di bawah ini : Tabel 9. Ringkasan Uji Hipotesis Data Pretes

\begin{tabular}{|l|c|c|c|}
\hline \multicolumn{1}{|c|}{ Data } & $\begin{array}{c}\text { rata- } \\
\text { rata }\end{array}$ & thitung & t tabel \\
\hline $\begin{array}{l}\text { Pretes } \\
\text { Eksperimen }\end{array}$ & 30,94 & \multirow{2}{*}{1,500} & 2,002 \\
\cline { 1 - 2 } $\begin{array}{l}\text { Pretes } \\
\text { Kontrol }\end{array}$ & 34,38 & & \\
\hline
\end{tabular}

Hasil pengujian hipotesis satu pihak diperoleh harga $t_{\text {hitung }}>t_{\text {tabel }}$ yaitu $5,472>1,679$ pada taraf signifikansi $\alpha=0,05 \mathrm{dan} d \mathrm{k}=62$. Hal ini berarti hipotesis alternatif (Ha) diterima yaitu ada pengaruh yang signifikan antara hasil belajar fisika siswa dengan menggunakan Strategi Genius Learning terhadap hasil belajar siswa X semester II SMA N 1 Siabu.
Tabel 10. Ringkasan Uji Hipotesis Data Postes

\begin{tabular}{|l|c|c|c|}
\hline \multicolumn{1}{|c|}{ Data } & $\begin{array}{c}\text { rata- } \\
\text { rata }\end{array}$ & $t_{\text {hitung }}$ & $t_{\text {tabel }}$ \\
\hline $\begin{array}{l}\text { Postes } \\
\text { Eksperimen }\end{array}$ & 77,34 & 5,472 & 1,6791 \\
\hline $\begin{array}{l}\text { Postes } \\
\text { Kontrol }\end{array}$ & 65,94 & & \\
\hline
\end{tabular}

\section{Pembahasan Hasil Penelitian}

Dibawah ini disajikan grafik nilai rata-rata akhir hasil belajar siswa.

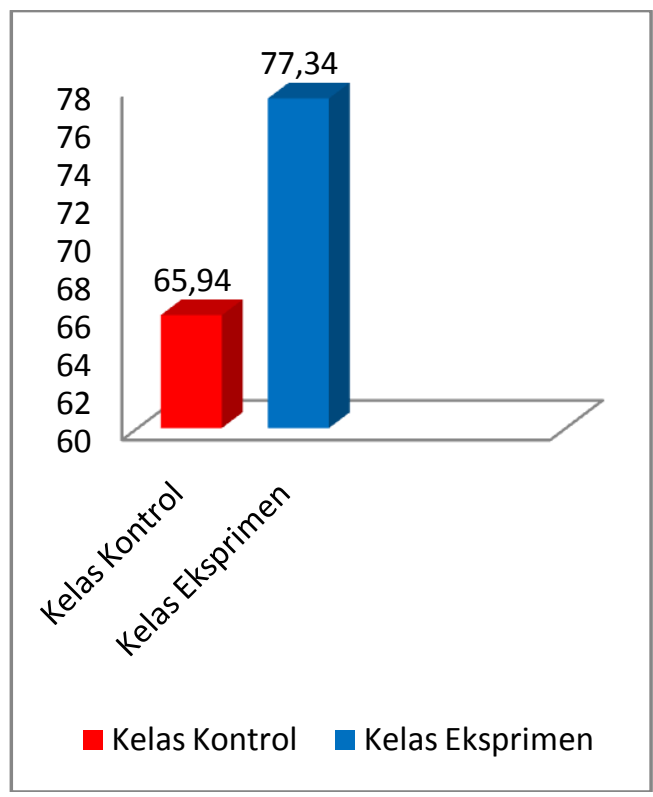

Gambar 4. nilai rata-rata akhir hasil belajar siswa

Berdasarkan hasil nilai di atas menunjukkan bahwa nilai rata-rata hasil belajar siswa pada materi pokok suhu dan kalor di kelas X-1 setelah diberi pembelajaran dengan Strategi Genius Leraning lebih tinggi dibandingkan nilai rata-rata hasil belajar siswa yang diberikan dengan pembelajaran konvensional pada kelas X-2. Hal ini juga ditemukan oleh Siagian (2012), yang mengatakan bahwa ada pengaruh yang signifikan 
terhadap hasil belajar fisika siswa yang diberi perlakuan dengan menggunakan Strategi Genius Learning pada materi pokok suhu dan kalor semester II di SMA N 1 Siabu T.A 2013/2014.

\section{PENUTUP}

\section{Kesimpulan}

Penerapan Strategi Genius Learning Terha dap Hasil Belajar Fisika Siswa Pada Materi Pokok Suhu Dan Kalor kelas X semester II di SMA Negeri 1 Siabu T.A. 2013/2014 memberikan pengaruh yang signifikan terhadap hasil belajar siswa. Berdasarkan kesimpulan secara umum, selanjutnya juga dapat ditarik kesimpulan secara khusus, antara lain: (1) Hasil belajar siswa kelas eksperimen dengan menerapkan Strategi Genius Learningsebelum diberikan perlakuan dengan rata-rata pretes sebesar 30,94 dan setelah diberikan perlakuan rata-rata postes siswa sebesar 77,34 dengan kategori tuntas. (2) Hasil observasi aktivitas belajar siswa dalam proses pembelajaran dengan Strategi Genius Learning pada materi pokok suhu dan kalor di kelas $\mathrm{X}$ semester II SMANegeri1 Siabu tahun ajaran 2013/2014 diperoleh rata-rata 76,79 dengan kategori aktif.

\section{Saran}

Dalam penelitian ini saran yang dapat disampaikan adalah (1) Sebelum melakukan penelitian, menjelaskan terlebih dahulu secara lebih rinci tentang strategi Genius Learning dan pembelajaran yang akan diterapkan di kelas agar dalam pelaksanaannya lebih kondusif. (2)
Pada tahap aktivasi, ulangi dan jangkarkan untuk membuat permainan yang lebih berpariasi tapi terkontrol agar pembelajaran lebih seru. (3) Penelitian ini hanya dilakukan pada pokok bahasan suhu dan kalor sehingga perlu dilakukan penelitian lebih lanjut tentang pembelajaran fisika pada pokok bahasan lain dengan menggunakan kecerdasan dominan siswa.

\section{DAFTAR PUSTAKA}

Anasofia, (2010), Mengapa Fisika Itu Penting Dalam Kehidupan Sehari-Hari,

http://anasofiana.students-

blog.undip.ac.id, di akses 30

September 2010.

Arikunto, S., (2010), Prosedur Penelitian Suatu Pendekatan Praktik (Edisi Revisi 2010), Rineka Cipta, Jakarta.

Devi, A., C., (2014), Pengaruh Penerapan Strategi Genius Learning Berbasis Multiple Inteligences Terhadap Hasil Belajar Siswa Pada Materi Elastisitas Di Kelas XI Madrasah Aliyah Negri Surabaya, Jurnal Inovasi Pendidikan Fisika(JIPF), Volume 03: 79-84.

Gunawan, W., A., (2012), Genius Learning Strategi Petunjuk Praktis Untuk Menerapkan Accerelated Learning, Gramedia Pustaka Utama, Jakarta.

Hasbullah, (2008), Dasar-Dasar Ilmu Pendidikan, RajaGrafindo Persada, Jakarta.

Rohani, A., (2004), Pengelolaan Pengajaran, Rineka Cipta. Jakarta. 
Siagian, H dan Susanto, I., (2012), Pengaruh Strategi Pembelajaran Genius Learning Terhadap Hasil Belajar Fisika Siswa, Jurnal Pendidikan Fisika, Volume 1: 4348.

Suliyono, (2013), Pengaruh Pendekatan Genius Learning Berbasis Kerja Ilmiah Terhadap Prestasi Belajar Fisika Ditinjau dari Pengetahuan Awal Siswa SMPN 13 Balikpapan Tahun 2012, Jurnal Pascasarjana Universitas Negeri Malang, Volume 1: 243-248.

Syahalam, (2013), Mamfaat Belajar Fisika, http://word press.com, di akses April 2013 